\title{
THE HEALTH OF \\ JAMES THE SIXTH OF SCOTLAND \\ AND FIRST OF ENGLAND*
}

BY

ARGHIBALD L. GOODALL M.D., F.R.C.S.Ed., F.R.F.P.S.Glasg.

To the Scot, James VI is a tantalizing figure. The unravelling of his serpentine policies has fascinated many scholars for centuries, and the material now available is so contradictory that its very existence is an embarrassment. To the Scots doctor, James is remembered for his grant of a charter to the Royal Faculty of Physicians and Surgeons of Glasgow in I599, and for his 'Counterblaste to Tobacco'. It is an act of piety to determine whether his complex actions might not be attributed to his physical ill-health, rather than to mere duplicity. Apart from a long and fascinating account of his death by Norman Chevers published in the Indian Annals of Medical Science (1862) and a medical report of Sir Theodore Mayerne, there is not much written on his medical history, although most writers on James refer en passant to his health. I shall attempt in this article to review the medical facts recorded and try to draw conclusions from them.

James was born in Edinburgh Castle on 19 June 1566 at 1o a.m. His mother, Mary Queen of Scots, immediately sent for her husband, Henry Darnley, and addressed him in these unhappy words: 'My lord, God has given you and me a son, begotten of none but you. . . . My lord, here I protest to God, as I shall answer to Him at the great day of judgement, this is your son and no other man's son' (Pitcairn). At once we are confronted with the question of the parentage of this child. Mary had married Darnley in 1565 , but the marriage was already a failure, and Darnley had been present at the murder of Mary's favourite, Rizzio, on 9 March 1566. Some gossip suggests that Rizzio might have been the father of James, but there is no shred of evidence that this was so. A more likely explanation of the intrigues of Mary's reign is that of Armstrong Davison (I956) who suggested that Darnley attempted to make Mary abort by attacking Rizzio in her presence, and later attempted to kill Mary at Kirk o' Field, being caught in his own plot by Bothwell. His object was to destroy Mary and her child, and to claim the thrones of Scotland, and later England, for himself.

There is another fascinating piece of gossip that James was a changeling,

* Presidential Address to the Scottish Society of the History of Medicine. 12 October 1956. 


\section{Archibald L. Goodall}

by some supposed to be a son of the Countess of Mar, which is impossible, and by others to be the son of a common woman of the Grassmarket of Edinburgh, purchased to foil Darnley's plot. It is said that the body of an infant was discovered last century in the wall of Edinburgh Castle, clothed in purple. I have been unable to confirm this rumour which might explain some of the discrepancies of James's character. James's early appearance, however, while not typically Stuart, had several of the characteristics of that family. The long jaw is particularly notable in contemporary portraits of James III and James VI.

At the age of five days he was seen by Henry Killigrew, who reported in these enthusiastic words: 'I was brought to the young prince, sucking of his nurse, and afterwards saw him as good as naked ... all to my judgement well proportioned and like to prove a goodly Prince' (Cal. Scottish Papers, a). Yet the Biographical Dictionary of Eminent Scotsmen (1869) remarks that he 'carried in his constitution a weakness of the most lamentable nature, affecting both his body and his mind'. James was baptized according to Roman Catholic ritual in Stirling Castle in December I566, when his father, although in the town, did not attend the service, while Bedford, Elizabeth's envoy, and the Protestant lords stood outside the chapel.

He was taken to the Earl of Mar at Stirling in March 1567 and, after the abdication of his mother, was crowned in the parish kirk there on 29 July ${ }^{2} 5^{6} 7$ at the age of thirteen months. Thus he never remembered a time when he had not been king or, indeed, when his body was not a pawn in the politics of the time.

His childhood companion was the son of the Earl of Mar, and his tutors were the renowned, though unsympathetic, George Buchanan and Peter Young. He was at first attended by a wet nurse, of whom no details are available, and by four 'rockers'. His youth was complicated by many attempts to seize his person and by the policies of Mar and Morton. In I578, after a plot by Atholl and Argyle, he nominally took over the government himself at the age of twelve.

In I 579, James first entered Edinburgh, and that fateful year also saw the appearance of the first of his evil geniuses. Esmé Stuart, Seigneur D'Aubigny, was the son of John Stuart, brother of James's grandfather, the Earl of Lennox. He was sent by the Guise faction to spy on the young James and his court, but, being an opportunist, he rapidly realized that his influence with James was of more value to himself than were his hopes if Mary were restored. James's taste for beautiful young men was first awakened by Stuart, whom he rapidly made Earl, and later Duke, of Lennox. Contemporary hints of the nature of this friendship are not wanting. Moysie wrote, 'His Majesty, having conceived an inward affection for the Lord D'Aubigny, entered in great familiarity and quiet purposes with him'. 


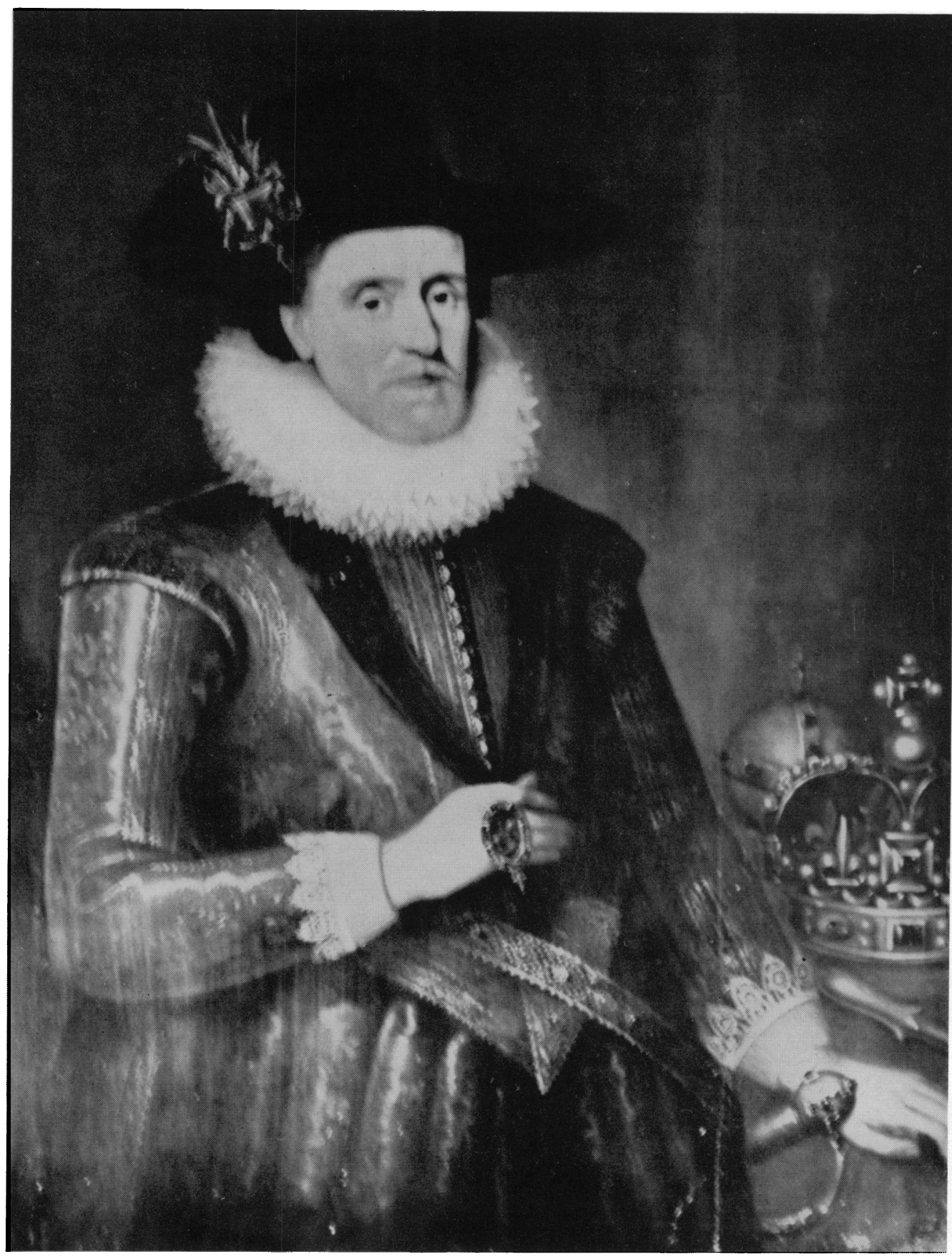

KING JAMES THE SIXTH

(From the portrait in the Royal Faculty of Physicians and Surgeons of Glasgow) 







\section{The Health of James the Sixth and First}

John Hacket remarked, 'I pray the reader to consider the sweetness of the King's nature, that from the time he was fourteen years old and no more, that is, when the Lord D'Aubigny came into Scotland, even then he began and with that noble personage, to clasp some one Gratioso in the embraces of his great love, above all others'. In the accusation of the Scottish clergy it is remarked that the Duke of Lennox 'went about to draw the King to carnal lust' (Galderwood).

Another vicious young man in the King's set at this time was Captain James Stewart, later Earl of Arran. His licentious behaviour was a byword and his wife was little better than a harridan. From them James picked up his lifelong habit of swearing. When Lennox was overthrown in 1582, after four years as favourite, Arran seized political power. In 1584, after the plot by the Ruthven lords failed, the Earl of Gowrie was executed.

In I 585, Arran fled on the return of the exiled Ruthven lords and remained in obscurity. Young Lennox now became first favourite.

A description of James at this time remarked that he was well instructed in languages, science and affairs of state, 'better, I dare say, than anyone else in his Kingdom' (Fontmay). But he was timid and disliked dancing, music and especially ear-rings. He had three defects: he failed to realize his own poverty, he had a great love for his favourites, he was lazy.

Now arose the most distressing conflict in James's character and one which he did not resolve as we might wish. Mary's complicity in the Babington plot was probably incontrovertible and James was forced to choose between his mother and his chance of succeeding to the throne of a united kingdom. He chose the latter and Mary was executed on 9 February 1587 without much protest from her son. We should, however, remember that James had not seen his mother since infancy, and there was no opportunity for them to develop normal family ties of affection. In spite of this apparent desertion of the Catholic faction, James still preserved contact with the Catholic nobility and Spanish agents.

In 1589 , it is noted 'that the King never regards the company of any woman, not so much as in any dalliance' (Cal. Scottish Papers, b), but dynastic demands led him to contemplate marriage, and Anne of Denmark was chosen in preference to Catherine, the sister of Henri IV. He wrote himself, 'I could have abstenit longair nor the weill of my patrie would have permitted ... nather use I to be sa caryed away with passioun as I refuse to heir reason. ...' (Papers Relative to the Marriage of King Fames.) King James, at this time, behaved like an amorous youth, and romantically sailed in winter to Oslo to bring home his new bride. Anne turned out to be extravagant and stupid, and embarrassed James's policies by becoming a Roman Gatholic.

James's policies at this time were indeed serpentine. He favoured the 


\section{Archibald L. Goodall}

Catholic earls of Huntly, Errol and Angus. He particularly loved Huntlyit is thought that this King is too much carried by young men that lie in his chamber and are his minions' (Cal. Scottish Papers, c). He also favoured the Earl of Bothwell, though eventually the bad behaviour of this reprobate led him to outlawry. Both sides on many occasions attempted to seize the King's person, and he was in a constant state of uncertainty and of scheming. He himself attempted to please all parties and finished by pleasing none. The murder of Moray by Huntly and the affair of the Spanish blanks (1592) demanded action by James and he marched north in I593. The Gatholic lords fled, but James did not complete his punitive expedition, much to the annoyance of Elizabeth of England. He had to return with Argyle in 1595 when he burned the houses of Huntly, Errol and Angus and banished them. Nevertheless, Errol and Huntly returned in 1596.

James's family consisted of Henry (I 8 February 1594), Elizabeth (1596), Margaret (1598) (died in infancy), Charles (I600) and Robert (1602). Anne had a miscarriage in 1603 and two other children died in infancy. These children appear to have been healthy at birth, and an infantile death rate of 50 per cent is not unusual for the times. Henry was a fine physical specimen and had an attractive personality. Peter Lowe, the founder of the Royal Faculty of Physicians and Surgeons, was his 'chiefest chirurgiane'. I have often thought that, but for his early death in I6I2 of typhoid fever, the Civil War might have been averted. Elizabeth seems to have been an attractive girl, and her later tribulations were due more to her father and her husband, the Elector of Hanover, than to her own devising. Gharles and his character would need a paper to himself, but physical illness was not evident in his early life.

In 1600 happened one of the most puzzling affairs in Scottish history, the Gowrie conspiracy. I am reminded of Andrew Lang's story of the old Scotswoman whose end was drawing near, and whose minister was called to break the news gently to her. The old lady pondered quietly for a moment and then she said, 'Ah, well, meenister, at least now we'll know the truth about the Gowrie conspiracy.' A very short résumé must suffice here, but there are so many facets of this ploy that historians still argue over them. I have followed mainly Andrew Lang and the King's own story.

After the Ruthven Raid in 1582, the Earl of Gowrie, one of the chief participants, was executed in 1584 . Despite this, his son was allowed to succeed to his estates, and his younger son, the Master of Ruthven, became something of a favourite of James. Their sister, Beatrix, was among Anne's ladies-in-waiting.

On 5 August 1600 , James was preparing for the hunt when he was approached by the Master of Ruthven with whom he held secret converse for fifteen minutes. The hunt proceeded and, during it, James asked Lennox 


\section{The Health of James the Sixth and First}

his opinion of Ruthven. Lennox replied that he knew no ill of the boy. A buck was slain at ro a.m. James and Ruthven then galloped off to Gowrie's house in Perth, leaving behind Lennox and Mar on tired horses. After a considerable time, dinner was prepared for the party and, in the midst of this, James and young Ruthven left the main dining hall and ascended a stair, locking several doors after them. An attempt by Lennox to follow was foiled by Ruthven. They then emerged in a turret-room where a man called Henderson awaited fully armed. The proceedings hereafter are not clear. Some even deny that Henderson was present, although he himself confessed. Meantime, the Earl of Gowrie had told the King's attendants that James had left the house and, but for the protestations of the gateman, they would certainly have departed. By chance, they were under the turret window overlooking the street. After a tussle, James managed to call to his followers through the window, 'I am murdered! Treason!' and they released him, killing both Gowrie and the Master of Ruthven. Other versions say that James was in the room for two and a half hours before he called for help.

The only point of the story which concerns us today is why James should go off with a man whose father he had executed, and put himself in the power of his enemies. The story of the pot of gold, supposedly Jesuit gold, which James said he was seeking, is too tenuous for our belief, and certainly James was no fool regarding his personal safety. He instructed his friends to strike the Master high 'because he has a chain doublet upon him'. A strong suspicion must be aroused that James was enticed away again by a young man of pleasing appearance. There may have been another motive on the Ruthven side for the affair, in which I must refer you to Andrew Lang, who suggests that Gowrie sought the crown. James himself may have engineered the affair to eliminate his enemies and rid himself of some of his creditors.

After this affair, James proclaimed that 5 August should be a day of national rejoicing, and accounts of the conspiracy written or inspired by him appeared which make the story more complicated and more inexplicable than it really was.

Elizabeth of England died on 24 March 1603, and James set out on the long-awaited journey south on 3 April. At Burghley, he fell from his horse and broke his collar-bone. In spite of this, his progress was triumphal, but he disliked crowds, and his comments on them were coarse.

There now appear many pen portraits of the new monarch, most of them obviously flattering: 'His colour blond, his hair somewhat the same, his beard square and lengthy, his mouth small, his eyes blue, his nose curved and clean-cut, a man happily formed ... neither too large nor too small . . . his countenance handsome, noble and jovial' (Cal. State Papers, Venice). 


\section{Archibald L. Goodall}

Wilson was nearer the truth when he described him as 'somewhat plump, of a ruddy complexion: hair light brown, tinged with white. His beard was scattered on his chin and very thin'.

Another young man appeared, Montgomery, whose 'comely person .. . made him the first who drew the King's eyes towards him with affection' (Cal. Hatfield House MSS.). The manners of the court deteriorated, even personal cleanliness became unusual, and James is reputed never to have washed. James was not a drunkard but often drunk and had little taste in wine. 'He errs as to quality, quantity, frequency, time and order. He promiscuously drinks beer, ale, Spanish wine, sweet French wine, white wine ... Muscatelle and sometimes Alicant wine' (Mayerne).

The years after his succession to the English crown were years of intrigue and duplicity. All his friends suffered and poor Salisbury was ill repaid for his labours in keeping the purse full and the King popular. James's attempts to achieve true union of the peoples were thwarted and his only real success was the Authorized Version. The Gunpowder Plot made James's cowardice even more apparent. 'He could not endure a soldier or to see men drilled, to hear of war was death to him ... . how he tormented himself with fear of some mischief may be proved by his great, quilted doublets, pistol proof ...' (Oglander).

After the death of Prince Henry in 1612, James suffered acutely from grief and melancholy. This was accompanied by some digestive disturbance and he seems to have been genuinely upset. However, within three months, the marriage of his daughter, Elizabeth, to the Elector of Hanover occurred with extravagant rites, and we find James asking his usual concupiscent questions of the newly married couple.

James was a patron of learning, giving a charter to Edinburgh University in 1582 . He was, however, not impressed by the medical profession and often twitted them. Yet he founded the Royal Faculty in 1599 and the Society of Apothecaries in I6 I 7. His 'Counterblaste to Tobacco' has almost a modern ring, and his method of high taxation of the commodity is completely up to date.

About the age of forty-five, James began to have bouts of serious ill health. Twice in 1613 he had nephritis and, later that year, arthritis. Mayerne noted that pains invaded the King's right foot which had an odd twist when he was walking. He had several digestive disturbances apparently related to emotional upsets, but also probably associated with a passion for fruit, which he ate to excess and with great greed.

Another favourite now appeared, Carr, a man whose 'smooth appearance made him think there might be good anchorage for his most inmost thoughts' (Wilson). Willson remarks 'that this attraction for the King was physical there can be no doubt. Osborne remarked that when James pawed 


\section{The Health of Fames the Sixth and First}

his favourites so fondly in public, he was not likely to restrain himself in private'. Carr was an adventurer, whose marriage to Frances Howard provoked a scandal, and whose election to the earldom of Somerset produced much trouble for James. Somerset's influence lasted until I6I 4 when James met Villiers, and one of the complaints against the former favourite was his refusal to sleep in the King's bedroom.

The duplicity of James is seen at its worst in his treatment of Somerset. The favourite and his wife were accused of poisoning Sir Thomas Overbury, the wife pleading guilty and Somerset being found guilty. At their last meeting, 'the King hung about his neck slobbering his cheeks, saying, "For God's sake, when shall I see thee again? On my soul, I shall neither eat nor sleep till you come again", (Weldon). At the foot of the stair, he remarked coolly, 'I shall never see his face again.'

In January I6I6 James had an attack of gout and apparently felt in poor health. He had now grown old and was frequently ill. He had nephritis again in I6I9 and an illness which sounds like arthritis. He was most impatient of pain. His habits had deteriorated; he bolted his food and drank heavily. He had the strongest antipathy to water for drinking or washing'his skin was as soft as taffeta sarsnet, which felt so, because he never washed his hands, only rubbed his fingers lightly with the wet end of a napkin' (Weldon). He itched insufferably and was constantly attacked by colds and sneezes. 'By his good will he would never change his clothes until worn out to very rags. . . . His eyes large, ever roulling after aney stranger cam in his presence, in so much as maney for shame have left the roome, as being out of countenance. His beard was very thin; his toung too large for his mouthe, wich ever made him speake full in the mouthe, and made him drinke verey uncomlie as if eatting his drinke, wich cam out into the cupe in eache syde of his mouthe' (Weldon).

Villiers was now Buckingham, the curse of James and his son, Charles. Oglander wrote, 'The King loved young men, his favourites, better than women, loving them beyond the love of man to woman. I never yet saw any fond husband make so much or so great dalliance over his beautiful spouse as I have seen King James over his favourites, especially Buckingham' James himself wrote to Buckingham, 'I pray thee haste thee home to thy dear dad by sunsetting at the furtherest, and so Lord send me comfortable and happy with thee this night' (Letters of Buckingham).

Queen Anne died on 2 March 16r9. James immediately became ill with renal stones and arthritis. He could not sleep, had fever, hiccough,"diarrhoea and an irregular pulse for eight days. He passed three urinary stones (Cal. State Papers, Domestic, a).

In I62I, James had to be carried to Parliament in a chair, 'being so weak in his legs and feet that it is doubted he will find little use in them 


\section{Archibald L. Goodall}

hereafter' (Cal. State Papers, Domestic, b). Later that year his horse stumbled and cast His Majesty through the ice into the New River. 'He fell in so that nothing but his boots were seen ... then came much water out of his mouth and body' (Ghamberlain) (Cal. State Papers, Domestic, c).

James became broken, debauched and repulsive in senility soon after he was fifty. The best medical report on him dates from this time, and was made by Sir Theodore Mayerne in 1623. This man was born in 1573 and settled in London practice in $16 \mathrm{I}$. He attended Prince Henry in 1612 . Mayerne's report is in modern form and gives a very full past history. He wrote that James had a drunken wet nurse and suckled for one year. He was not able to walk until the age of six years, attributed to the bad milk of his drunken nurse. Between the second and fifth years he had smallpox and measles. Aged five, he had suppression of urine for twenty-four hours. He suffered from colic frequently up to the age of twenty-four, and had frequent diarrhoea, especially at the age of forty-four. Aged forty-six, he had a period of melancholy after the death of Henry. The next year he had his first attack of renal colic. Two years later he began to have pains in the joints and 'nephritis', during which disease he passed thick sand and a calculus. $\mathrm{He}$ had frequent swelling of the feet and legs and when fifty-seven had a pain in his thigh and wasted feet.

His minor complaints included a fractured collar-bone, enlarged right axillary glands and a right olecranon bursitis.

His social habits were bad. He drank too much and the wrong sorts of wines. He did not smoke.

On examination, Mayerne found a man older-looking than his years with a broad chest and sound organs. He was of a wrathful and melancholy nature and had frequent insomnia. His legs seemed too small for his body and he required help to walk. He was easily affected by cold and damp and his lungs were often affected by bronchitis. His appetite and digestion were good, and he was always ready for food. His fauces appeared narrow so that he had difficulty in swallowing. $\mathrm{He}$ ate no bread and bolted his food unchewed, as he had no teeth. He was excessively fond of fruit. His bowels were regular, though he suffered from flatulence. He had haemorrhoids which bled regularly and gave him ease.

The kidneys readily developed sand and gravel. The skin was thin and delicate and itched very easily.

This report suggests several diagnoses. In general, James was a done old man. The wasted feet, pain in the thigh and swelling of the legs indicate peripheral vascular disease, probably of atherosclerotic origin. There was probably also cerebral vascular disease. The kidney lesion was probably pyelonephritis.

James did not long outlive this report. He became puerile and futile. 


\section{The Health of James the Sixth and First}

His last two years were tormented by the foolhardy exploits of Charles and Buckingham (dear Steinie) seeking a wife in Spain.

There can be little doubt of the relations between James and Buckingham. In 1623 , this latter wrote, 'I cannot now think of giving thanks for friend, wife or child; my thoughts are only bent on having my dear dad and master's legs soon in my arms. . . .' In I624, James wrote to Buckingham, '... and so God bless you, my sweet child and wife, and grant that you may ever be a comfort to your dear dad and husband' (Halliwell).

The summer in 1624 was dry and the King remained fairly well. In the autumn he had severe arthritis and became very depressed. In March I625 he took an ague and became seriously ill. He had numerous remedies, some official and some unofficial, applied by Buckingham and his mother, but died peacefully on 27 March 1625 . His terminal hours were marked by a stroke, a swollen tongue and diarrhoea.

The evidence for the cause of James's death is fully considered by Chevers in his long and detailed article in the Indian Annals of Medical Science. The suggestion that he was poisoned stems from hatred of Buckingham, and was promulgated by Eglisham, a physician. The evidence is scanty and Chevers concluded that poison was not a cause of death. Nevertheless, Felton claimed that Eglisham's book was the reason for the murder of Buckingham. Article XIII of Buckingham's impeachment tells the story of the administration of Remington's Nostra, and of the dismissal of Dr. Craig for accusing Buckingham in the King's presence of poisoning James. These tales have a political flavour and no case is made out for regicide. Even James's remark, 'Would to God I had never taken it, it will cost me my life,' might be a jocular remark made during an attack of diarrhoea. The only extant copies of Eglisham's pamphlet are dated 1642, and seem more for the purpose of embarrassing Charles than of elucidating his father's death.

Sir Robert Gordon stated that Buckingham did not visit the King's body, and that it lay naked for eight days covered only by a sheet.

The post-mortem findings are recorded by several observers. William Walton, surgeon, was paid $£ 5^{\circ}$ for embalming the body (Cal. State Papers, Domestic, d). Mead wrote that the heart was of extraordinary bigness, that all the organs were sound, that the head was very full of brains and that the blood was tainted with melancholy. William Nive wrote, 'The King's body was about the 29th of March disbowelled and his heart was found to be great but soft, his liver fresh as a young man's, one of his kidney's very good but the other shrunk so little as they could hardly find it, wherein there was two stones. His lites and gall blacke, judged to proceed of melancholy. The semyture of his head so stronge as they could hardly break it open with a chisell and a sawe; and so full of braynes as they could not, upon this 


\section{Archibald L. Goodall}

openinge keepe them from spilling; a great mark of his infinite judgement' (Brit. Med. F., Igro).

The modern physician considering these facts must not be too credulous. Many of the flattering records are obviously not entirely true. Similarly, many of the derogatory descriptions are political rather than accurate. The late walking and deformed foot suggest rickets in childhood. He then became a reasonably healthy young man with the sexual ambivalence of the Renaissance which stayed with him throughout life. Arthritis seems to have affected him at a comparatively early age, and pyelonephritis with stones must have made his life miserable. He seems to have had atherosclerosis probably affecting his limb vessels, and he finally suffered a cerebral haemorrhage.

These lesions were likely to upset a man of James's temperament, but his psychological assessment is even more difficult. No doubt his infantile exploits created a feeling of insecurity which lasted his lifetime. No doubt his flatterers led him to believe that his judgement was infallible. Yet some of his decisions were manifestly dishonest and many of them craven. Even after he had succeeded Elizabeth, his cynical disregard of justice and equity is far from admirable. One can only suggest that early atherosclerosis had impaired his mental processes. The lack of affection of his childhood may have caused his over-indulgence in affection for his favourites.

Thus lived and died James VI, 'the wisest fool in Christendom', 'God's silly vassal', the first King of Great Britain, the inspirer of the Authorized Version of the Bible, the intriguer between Protestant and Catholic, the glutton, the poet, the moral reprobate, the coward, the founder of the Royal Faculty of Physicians and Surgeons. The choice is yours; I choose King James, the founder of the Royal Faculty of Physicians and Surgeons.

\section{God Save the King!}

\section{REFERENCES}

Biographical Dictionary of Eminent Scotsmen. Edited by T. Thomson. London, 1869. British Medical Journal. 'Some Royal Death Beds'. I910, I, 1363.

Bucking ham. Letters of the Duke and Duchess of Buckingham. Edinburgh, 1834 .

Galde R W OOD, D. History of the Kirk of Scotland. Edinburgh, Woodrow Society, 1842.

Calendar Hatfield House MSS. Cited in Wilsson.

Calendar Scottish Papers. a, II, 290; b, Ix, 655; c, Ix, 701.

Calendar State Papers, Domestic. a, Vol. cVII, No. 6; b, Vol. cxIx, No. 64; c, Vol. cxxvII, No. 26; d, App. 1625-26, p. 564.

Calendar State Papers, Venice, 1603-07. 39.

Ghamberlain, J. Letters. London, I86r. Cited in Willson.

Ghevers, N. Indian Ann. med. Science. 1862, xv, 187.

Сов ветт. Complete Collection of State Trials. London, 1809.

26 


\section{The Health of James the Sixth and First}

Davison, M. H. Armstrong (1956). Proc. Scottish Soc. Hist. Med., 1955-56.

Dictionary of National Biography. London, 1885 et seq.

Eglish am, G. The Forerunner of Revenge. London, 1642.

Fleming, D. H. In Scottish History and Life. Glasgow, 1902.

FONTMAY. Cited in Willson.

Hacke T, J. Scrinia Reserata. London, 1693.

HALliWE LL-Phillip Ps, J. O. Letters of the Kings of England. London, 1846.

HeNDERSON, T. F. Mary Queen of Scots. London, 1905. Fames I and VI. London, 1904.

LANG, A. Fames VI and the Gowrie Mystery. London, 1902.

MAYerne, T. Cited in Moore.

MOORE, N. The History of the Study of Medicine in the British Isles. Oxford, 1908.

Moysie, D. Memoirs of the Affairs of Scotland. Edinburgh, Maitland Club, 1830.

OGLANDER, J. Memoirs of Sir Fohn Oglander. London, 1888.

Papers Relative to the Marriage of King James the Sixth of Scotland. Edinburgh, Bannatyne Club, 1828.

Pitcairn, R. Historical Memoirs of the Reign of Mary Queen of Scots, etc. Edinburgh, Abbotsford Club, 1836. Criminal Trials in Scotland. Edinburgh, 1833.

RAE, J. 'The Deaths of English Kings'. Clin. F., xxxIx, 202. 1912.

RIDDELL, W. R. 'The Death of James I'. Med. F. and Record, $\operatorname{cxxx}$, 343. 1929.

ScotT, W. Secret History of the Court of James I. Edinburgh, 181 r.

Weldon, A. 'The Court and Character of King James'. Section of Scott supra.

Williams o , H. R. Historical Whodunits. London, 1955.

WILLson, D. H. King James VI and I. London, 1956.

WiLson, A. The History of Great Britain, etc. London, 1653.

Wot ton, H. Letters and Dispatches to James I. London, Roxburghe Club, 1850. 